\title{
FOREIGN BANKS IN CENTRAL AND EASTERN \\ EUROPE: THE GOOD, THE BAD AND THE UGLY*
}

\author{
Mihai Niţoi ${ }^{\text {(D) }}$, Dorina Clichicia ${ }^{\text {(D) }}$, Simona Moagăr-Poladiana
}

\begin{abstract}
Foreign banks have played a major role in Central and Eastern European economic landscape over the last decades. They have spurred banking intermediation and fuelled economic growth for years. However, the global financial crisis unveiled the other side of the coin. This article analyses foreign banks' lending behaviour in Central and Eastern Europe over the period from 2000 to 2016. It aims to investigate the nexus between bank loan growth, cross-border bank claims and the cycle period. Moreover, it captures the impact of the financial cycle on foreign banks' credit behaviour and highlights whether foreign bank ownership is influenced by host- and home-country effects. Our findings reveal the strong nexus between foreign banks' loan growth and cross-border bank claims. Also, we emphasize the pro-cyclicality of foreign banks' loan growth and cross-border bank claims. Furthermore, we see clear differences related to foreign banks' lending behaviour during normal and turbulent times, triggered by host- and home-country effects. These results raise policy challenges regarding the right bank ownership balance and the use of prudential regulation.
\end{abstract}

Keywords: Foreign banks, loan growth, cross-border bank claims, financial crisis, Central and Eastern Europe

JEL Classification: F21, F36, G21

\section{Introduction}

The transition from central planning to a market-oriented economy has changed the banking landscape in Central and Eastern Europe (CEE) profoundly. During the early 1990s, CEE countries established a two-tier banking system, liberalized bank licensing, established regulatory and supervisory systems, and restructured state-owned banks through privatization. Countries tried different approaches to privatization, but not all

\footnotetext{
* This work was supported by a grant of the Romanian Ministry of Education and Research, CNCS - UEFISCDI, project number PN-III-P1-1.1-TE-2019-0415, within PNCDI III.

a Institute for World Economy, Romanian Academy, Romania

Email: mihai.nitoi@iem.ro, dorina.clichici@iem.ro,poladian@iem.ro
} 
have been successful. During the first wave, several countries, such as Poland, Czechia and Slovakia, decided to reform their state-owned banks as quickly as possible through so-called large-scale or voucher privatization. However, the lack of a legal and institutional framework to support this transfer of ownership did not help to recapitalize and increase bank efficiency in these transition economies. During the second wave of banking reform, CEE governments were looking to strengthen efficiency, increase competition and take advantage from transfer of knowledge from international banks. In line with these motivations, countries have adopted a more successful method of privatization, i.e., an in-depth approach, consisting in takeovers of state-owned banks by foreign strategic investors.

Due to low levels of risk aversion and interest rates, higher profits than domestic peers (Claessens et al., 2001), and because of their greater net economic advantage (Berger, 2007), banking groups from advanced countries became one of the major investors in the CEE region. They came to expand across borders at a quite rapid pace, leading to an unprecedented rise in cross-border bank claims, the largest among emerging or developing regions (Becker et al., 2010). Furthermore, the goal of European Union membership pursued by these governments fostered this pattern. Consequently, the market share of foreign banks in the CEE region expanded from an average of around $10 \%$ in 1995 (Cull et al., 2017) to a pre-crisis peak of 77\% in 2008 (European Central Bank, 2020). Foreign bank ownership and cross-border bank claims have come to play a major role in the economic and financial development of the CEE region. However, the story revealed the two sides of the coin, both the positive and the negative one.

In general, the benefits brought by foreign banks in the region are unanimously acknowledged in the literature. Bonin et al. (2005) documented that foreign-owned banks in CEE transition economies were more cost-efficient, while banks with a strategic foreign owner provided better services. Lapteacru (2016) found that foreign subsidiaries in the CEE are less risky than the banks owned by the state. More than that, the performance of the entire banking sector increased due to foreign entry, both directly and indirectly, in these transition countries (Hasan and Marton, 2003). Empirical results suggest that foreign subsidiaries in the CEE lowered the costs of financing (Havrylchyk and Jurzyk, 2011) and enhanced credit conditions for all firms (Clarke et al., 2006). In addition, they contributed to credit stability during domestic credit crises (Cull et al., 2017; De Haas and Van Lelyveld, 2006; Haselmann, 2006). There is evidence that foreign bank ownership was a mitigating factor in the output decline of the emerging Europe even during the 2008-2009 financial crisis (Berglöf et al., 2009).

Furthermore, foreign banks became the major supplier of credit in the CEE before the global financial crisis (GFC). They came to provide about $80 \%$ of total credit 
in the region (Allen et al., 2017; Arakelyan, 2018). Impavido et al. (2013) found that the main reasons for high cross-border bank claims in CEE countries were significant presence of foreign banks, the expansion of foreign currency loans and the centralized funding model of international banks. Consequently, CEE countries experienced an unprecedented credit expansion, associated with increased cross-border bank claims, which spurred economic growth. Data from the BIS (2020) reveal that cross-border bank claims towards the region climbed from approximately USD 29 billion at the end of 2000 to a peak of about USD 295 billion by the end of 2008 . These were the good times concerning foreign bank ownership in the region.

The GFC uncovered the bad side of the same coin, when foreign banks' behaviour turned into an instability factor. While the credit supplied by these banks was a driver of economic growth before the crisis, it exacerbated domestic credit cycles and macroeconomic imbalances, i.e., higher current account deficits, higher inflation, lower competitiveness, higher housing prices and higher external debt levels. As the global risk aversion exploded and the interbank markets dried up after the Lehman Brothers' collapse, cross-border bank claims from Western European banks to their CEE subsidiaries dropped (Allen et al., 2011; Brunnermeier et al., 2012; De Haas and Van Lelyveld, 2014), leading to a contraction in domestic demand and economic growth. The CEE countries were hit harder than other regions in the world (Montoro and Rojas-Suarez, 2012; Klingen, 2013), especially countries with the largest pre-crisis macroeconomic imbalances (Becker et al., 2010; Bakker and Gulde, 2010). These were the bad times related to foreign-owned banks in the CEE region.

Data from the BIS (2020) reveal the sharp decline in cross-border bank claims towards the CEE region, from about USD 295 billion in 2008 to around USD 160 billion in 2016. In 2020, the cross-border claims of foreign banks in the CEE region climbed to approximately USD 182 billion. The share of foreign banks' assets in the CEE economies went down, from an average around $77 \%$ in 2008 to $71 \%$ in 2016 . This downward trend continued in the following years, reaching the value of 65\% in 2019 (European Central Bank, 2020). In turn, such a behaviour narrowed the credit supply and hampered the economic development in some of the countries. The risks posed by a sudden stop in credit supply by foreign banks were relieved in 2009 through the Vienna Initiative, which helped to ensure that foreign banks preserve funding and keep adequate capital in their CEE subsidiaries. Foreign banks gradually changed their business strategy in the CEE countries after the GFC, from relying on cross-border claims towards a more self-sustained local bank financing.

The impact on domestic credit of such a behaviour differs across CEE countries. The most severe credit bust episodes took place in Croatia, Hungary, Latvia, Lithuania, 
Romania and Slovenia (Duca et al., 2017). For these countries, these were ugly times. The basic catalyzer of the systemic crisis in the six economies was the excessive pre-crisis credit growth financed primarily through banks' cross-border claims. Apart from this, Duca et al. (2017) revealed several more crisis accelerators in these states, such as misaligned incentives, currency and liquidity mismatches, excessive bank leverage, exposure concentration to the real estate sector or mismatches and market illiquidity. Other countries managed to overpass the turbulent period without major negative implications, i.e., Bulgaria, Czechia, Estonia, Poland and Slovakia. Even if banks recorded an increase in the non-performing loan ratio and default rates during the GFC, high levels of bank capitalization and profitability, an adequate liquidity and low levels of foreign currency loans helped to absorb the losses without any systemic consequence. Moreover, Fišerová et al. (2015) found that more capitalized foreign banks had the ability to outperform their peers in the region.

Against this background, our paper aims to study the lending behaviour of foreign banks in the CEE region. In doing this, we have in mind several objectives. Firstly, we investigate the nexus between bank loan growth, cross-border bank claims and the cycle period. Secondly, we study the crisis effects on foreign banks' loan growth. Thirdly, we test whether the credit behaviour of foreign banks is influenced by host- and home-country effects in normal and turbulent times. In our view, the story of foreign banks in the CEE region offers a fruitful background for studying and achieving these objectives. We differ from the existing literature in several points of view. Numerous papers have studied the ownership effects on lending patterns in the CEE region (Allen et al., 2017; Cull and Pería, 2013; Chen and Wu, 2014; Iwanicz-Drozdowska and Witkowski, 2016; Drakos et al., 2016; Bonin and Louie, 2017). However, we differ from these by investigating the credit behaviour of foreign banks in relation with host- and home-country effects. Additionally, the paper contributes by exploring whether foreign banks' credit behaviour is time-varying and ownership-varying.

The rest of the paper is structured as follows: Section 2 provides the methodology and the data, Section 3 discusses the findings, and Section 4 concludes.

\section{Methodology and Data}

\subsection{Methodology}

Hereinafter, we depict the models used. The nexus between loan growth, banks' crossborder claims and the cycle period is explored by using the following base regression model: 


$$
Y_{i j, t}=\beta_{0} Y_{i, j, t-1}+\beta_{1} X_{j, t}+\beta_{3} \text { Cycle }_{t}+\varepsilon_{i, j, t}
$$

where, $i=1, \ldots, N ; j=1, \ldots, J ; t=1, \ldots, T ; i$ represents the bank; $j$ refers to the country; $t$ is the time variable; $Y_{i j, t}$ measures bank loan growth; $Y_{i, j, t-1}$ captures the lagged bank loan growth; $X_{j, t}$ is a set of variables used to depict the patterns of banks' cross-border claims in country $j$ in year $t$; Cycle $e_{t}$ is a time variable that accounts for cyclicality effects; and $\varepsilon_{i j, t}$ is an error term.

We have several concerns with regard to the estimation of the above equation. Firstly, in our view, the patterns of loan growth could also have an impact on cross-border bank claims. Therefore, the results might be affected by endogeneity. For example, a banking system that experiences a positive credit cycle attracts foreign investors and, consequently, foreign inflows. Conversely, a bust in credit activity could lead to bank outflows. Consequently, the potential positive nexus between loan growth and cross-border bank claims could also be driven by reverse causality. Secondly, the inclusion of a lagged dependent variable could lead to biased results. We mitigate these concerns by employing a generalized method of moments estimator. Following previous specifications, the endogenous variables are instrumented by their lagged values in levels, while the exogenous variables are instrumented by themselves (Blundell and Bond, 1998; Roodman, 2009). We use the Hansen test of over-identifying restrictions for testing the instrument validity and the second-order serial correlation tests for verifying the autocorrelation.

The relationship between the financial cycle and foreign banks' lending behaviour is studied by employing a multinomial logit model. In what follows, we describe the model set-up. Let $Y$ denote the phase of the financial cycle taking on values $\{1,2, \ldots, J\}$, where $J$ is the number of financial cycle phases, and let $X_{i}$ denote a set of conditioning variables. Under this framework, the probability $P_{j}$ for $j=2, \ldots, J$ that a variable is more prone to be characteristic to a certain financial cycle phase is given by the following specification:

$$
P_{j}=P\left(Y=j \mid X_{i}\right)=\frac{\exp \left(X_{i}^{\prime} \beta_{j}\right)}{\sum_{k=1}^{j} \exp \left(X_{i}^{\prime} \beta_{k}\right)}
$$

where $\beta_{j}$ is a vector of coefficients related to subgroup $j$. To identify the model, the coefficients for the reference $\beta_{1}$ are set to zero. Therefore, the equation becomes:

$$
P_{1}=P\left(Y=1 \mid X_{i}\right)=\frac{1}{\left[1+\sum_{k=1}^{j} \exp \left(X_{i}^{\prime} \beta_{k}\right)\right]}
$$

Finally, the relative probability of being in subgroup $j$ relative to the reference group is:

$$
\ln \left[P_{j} / P_{1}\right]=X_{i}^{\prime} \beta_{j}
$$


We choose the multinomial logit model because it allows us to investigate the differences in foreign banks' loan growth in normal and turbulent times, and to show whether foreign bank behaviour is biased by the host- and home-country effects. Furthermore, the multinomial logit model is attractive because it does not assume normality, linearity or homoscedasticity.

\subsection{Data}

Our data sample includes bank-level data, country data and foreign bank home-country data. We choose banking systems of 11 countries in CEE, i.e., Bulgaria, Croatia, Czechia, Estonia, Hungary, Latvia, Lithuania, Poland, Romania, Slovakia and Slovenia. In constructing the bank-level sample, we have in mind several criteria. Firstly, we select only commercial banks. Secondly, we exclude bank observations beyond $1 \%$ and $99 \%$ tails of all interest variables. Thirdly, we keep in our sample only banks that report continuously for ten years. Therefore, we include in our sample banks that followed a long-term strategy in the region. Finally, having in mind each country's foreign bank ownership patterns, we keep in our sample domestic banks and banks with ownership from Austria, Belgium, France, Germany, Greece, Italy and Sweden. Foreign banks from these countries account for approximately $70 \%$ of the total cross-border bank claims in our sample countries and over the sample period, according to BIS (2020). In order to identify bank ownership, we use the Claessens and Van Horen (2015) database. However, this database covers only the period from 1995 to 2013. Therefore, for 2014 to 2016, we collect ownership data from banks' annual reports and websites. The final unbalanced panel data comprises 1686 bank-year observations for the period from 2000 to 2016. Of the total, 793 are domestic bank-year observations, and 893 foreign-bank year observations. Bank data were extracted from the Bankscope database.

Additionally, as a proxy for the cross-border bank claim patterns, we use locational banking statistics (LBS) from the Bank for International Settlements (BIS), i.e., the ratio of cross-border bank claims to GDP of the BIS reporting banks and cross-border bank claims' growth. The reasons why we choose LBS are manifold. Firstly, LBS capture outstanding cross-border claims and liabilities of internationally active banks located in reporting countries, tracking how funds are transferred from sources in one country via banks to another country. Secondly, according to the BIS (2017), this data set provides useful information regarding potential fragilities in the financial system and helps to monitor the vulnerabilities linked to cross-border bank credit. Finally, studies using LBS have shown that cross-border credit is often a major driver of domestic credit booms, but also plays a role in the transmission of financial shocks across countries (Avdjiev et al., 2012; Borio, 2011; Bruno and Shin, 2012). 
Table 1: Descriptive statistics of variables used in regressions

\begin{tabular}{|c|c|c|c|c|c|}
\hline & Observations & Mean & Std. dev. & Min & Max \\
\hline Bank loan growth & 1,686 & 0.109 & 0.311 & -3.873 & 3.795 \\
\hline Domestic banks' loan growth & 793 & 0.109 & 0.331 & -3.873 & 1.730 \\
\hline Foreign banks' loan growth & 893 & 0.109 & 0.292 & -0.920 & 3.795 \\
\hline Foreign banks' loan growth in Bulgaria & 94 & 0.205 & 0.479 & -0.964 & 1.494 \\
\hline Foreign banks' loan growth in Croatia & 107 & 0.109 & 0.459 & -0.935 & 1.417 \\
\hline Foreign banks' loan growth in Czechia & 94 & 0.162 & 0.459 & -0.979 & 0.923 \\
\hline Foreign banks' loan growth in Estonia & 34 & 0.012 & 0.502 & -0.958 & 0.623 \\
\hline Foreign banks' loan growth in Hungary & 142 & 0.017 & 0.490 & -0.996 & 0.999 \\
\hline Foreign banks' loan growth in Latvia & 33 & 0.170 & 0.373 & -0.547 & 0.852 \\
\hline Foreign banks' loan growth in Lithuania & 31 & 0.216 & 0.399 & -0.783 & 0.866 \\
\hline Foreign banks' loan growth in Poland & 93 & 0.091 & 0.668 & -0.981 & 3.795 \\
\hline Foreign banks' loan growth in Romania & 122 & -0.003 & 0.497 & -0.975 & 1.418 \\
\hline Foreign banks' loan growth in Slovakia & 75 & 0.260 & 0.367 & -0.897 & 0.894 \\
\hline Foreign banks' loan growth in Slovenia & 68 & 0.054 & 0.448 & -0.975 & 0.946 \\
\hline Austrian-owned banks' loan growth & 220 & 0.092 & 0.269 & -0.914 & 1.417 \\
\hline Belgian-owned banks' loan growth & 53 & 0.104 & 0.181 & -0.190 & 0.497 \\
\hline French-owned banks' loan growth & 120 & 0.103 & 0.226 & -0.391 & 0.890 \\
\hline German-owned banks' loan growth & 98 & 0.149 & 0.485 & -0.674 & 3.795 \\
\hline Greek-owned banks' loan growth & 103 & 0.109 & 0.341 & -0.521 & 1.418 \\
\hline Italian-owned banks' loan growth & 191 & 0.104 & 0.233 & -0.897 & 0.981 \\
\hline Swedish-owned banks' loan growth & 108 & 0.129 & 0.274 & -0.920 & 0.715 \\
\hline Cross-border bank claims' to GDP ratio & 1,686 & 18.091 & 11.571 & 1.230 & 76.802 \\
\hline Cross-border bank claim growth & 1,686 & 0.079 & 0.321 & -0.923 & 1.173 \\
\hline
\end{tabular}

Source: Bankscope and authors' calculations.

To study the cyclicality effects, we have in mind three different periods, i.e., 2000-2007, 2008-2012 and 2013-2016. The first is a proxy for the pre-crisis period, the second for the turbulent period, and the third for the after-crisis period. We consider the period from 2008 to 2012 to be turbulent times, because during this interval most of our country sample was confronted with systemic banking crises or with residual 
events, which negatively impacted on the banking system. For each of the three variables, we have created a variable that takes the value of one, and zero otherwise.

In the multinomial logit model, the cyclicality variables are the outcome variables, while the predictor variables are bank loan growth. The outcome variables take values from one to three, corresponding to boom, crisis and after-crisis periods. Bank loan growth is computed for domestic banks, for foreign banks in each of our sample countries and for foreign banks with ownership from Austria, Belgium, France, Germany, Greece, Italy, and Sweden.

In order to emphasize differences in foreign bank behaviour in relation with economic cycle and to highlight whether the foreign bank ownership is home-country varying and time-varying, we interact dummy variables created for foreign banks with bank loan growth.

Table 1 lists the descriptive statistics of the variables used in regressions.

\section{Results and Discussion}

Table 2 depicts the results obtained by estimating Equation (1). Intuitively, in both models, the lagged variable of loan growth has a significant effect on bank lending behaviour. The findings of model (1), estimated for all sample banks, reveal a positive link between banks' cross-border claims to GDP ratio and loan growth. That is similar to the results of Cetorelli and Goldberg (2011), who showed that loan supply on emerging European markets was significantly affected during the crisis through a contraction in cross-border bank claims. The dummy for the pre- and after-crisis variables reveals the procyclical behaviour of bank loan growth. More exactly, we see that loan growth was approximately $32 \%$ higher in the boom compared with crisis times. The results are similar to other findings in the literature (Allen et al., 2017). Interestingly, no significant differences between the crisis and after-crisis bank behaviour are revealed. This result indicates that the deleveraging process that banks started in 2008 persisted after the crisis period.

Model (2) is employed for examining the nexus between cross-border bank claims' growth and loan growth for foreign banks. The coefficient indicates the positive relationship between the two variables. Furthermore, we emphasize a higher coefficient for the crossborder bank claims' growth than for the bank loan growth lag, revealing a stronger relationship between foreign banks' loan growth and cross-border bank claims. Our findings show that banks' cross-border claims played a central role in the foreign banks' lending pattern. The results are intuitive, if we bear in mind that foreign banks had fuelled the CEE region with funds before the crisis. These were the good times. However, during these times, foreign banks contributed to the boom of credit in the region and built up the prerequisites for some imbalances. In most of the CEE countries, credit growth relied upon cross-border 
flows compared to domestic and stable funds. Furthermore, especially in Poland, Hungary and Romania, cross-border bank funds fuelled foreign currency credits and, implicitly, enhanced foreign exchange risks. Also, the boom of credit increased the external balance deficit and led to a rapid rise of prices in the real estate sector.

Table 2: Nexus between bank loan growth and cross-border claims' growth

\begin{tabular}{l|c|c}
\hline Dependent variable: loan growth & (1) & (2) \\
\hline Bank loan growth lag & $0.240^{* * *}$ & $0.203^{* * *}$ \\
\hline Cross-border bank claims to GDP ratio & $0.004^{* *}$ & - \\
\hline Cross-border bank claims' growth & - & $0.291^{* * *}$ \\
\hline Pre-crisis & $0.305^{* * *}$ & $0.158^{* * *}$ \\
\hline After-crisis & -0.007 & -0.017 \\
\hline AR2 & 0.202 & 0.605 \\
\hline Hansen & 0.696 & 0.865 \\
\hline Observations & 1,686 & 893 \\
\hline
\end{tabular}

Note: ${ }^{* * *},{ }^{* * *}$, ${ }^{*}$ correspond to the $1 \%, 5 \%$, and $10 \%$ levels of significance, respectively.

Source: Authors' calculations.

Table 3 lists the results of the multinomial logit model. By using this model, we test the impact of the economic cycle on bank loan growth and study the time-varying nature of the ownership effect. The outcome measure is the nature of the economic cycle. For all the models, we have chosen to use the crisis period as the baseline category.

Model (1) clearly reveals the pro-cyclicality of banks' loan growth and cross-border bank claims' growth. If a bank increases the loan growth by one unit, the relative log odds of being in a boom period vs. a bust period would be expected to increase by 6.195 units, while keeping all the other variables in the model constant. The pro-cyclicality is even larger for cross-border bank claims. More exactly, if banks' cross-border claims grow by one unit, the relative log odds of being in a boom period vs. a bust period would be expected to increase by 8.722 units. The results for the after-crisis period are surprising. A one-unit increase in bank loan growth is associated with a decrease of 1.948 units in the multinomial log-odds of being in an after-crisis vs. a crisis period. Also, if crossborder bank claims grow by one point, the relative log odds of being in an after-crisis vs. a crisis period would be expected to decrease by 1.856 units. 
Models (2), (3) and (4) follow a top-down approach to analysing foreign banks' lending behaviour. Model (2) depicts differences in lending patterns, when we account for ownership effects. Specifically, we see that foreign banks had a higher loan growth rate in the boom period, and deleveraged more in the turbulent times compared to domestic banks. More exactly, if a foreign or a domestic bank increases the loan growth by one unit, the relative log odds of being in a boom period vs. a bust period would be expected to increase by 7.618 and 5.035 units, respectively, while keeping all the other variables in the model constant. Differences can also be depicted for the after-crisis vs. crisis period. A one-unit increase in foreign or domestic bank loan growth is associated with a decrease of 2.106 and 1.824 units, respectively, in the multinomial log-odds of being in an aftercrisis vs. a crisis period. Differences between domestic and foreign banks' credit behaviour in the CEE region were also emphasized by Cull and Pería (2013), Chen and Wu (2014), De Haas et al. (2015), Allen et al. (2017), and Niţoi et al. (2019). However, considering that our data include banks from 11 CEE countries, which may lead to a heterogenous sample, models (3) and (4) test whether foreign banks' loan growth is influenced by a hostand a home-country effect, respectively.

Model (3) reveals that banks' loan growth rates are influenced by host-country effects. For example, on the one hand, when a foreign bank in Bulgaria increases loan growth by one unit, the relative log odds of being in a boom period vs. a bust period would be expected to increase by 4.112 units, while all the other variables in the model remain constant. On the other hand, the results show no differences for the foreign banks' loan growth in Slovakia during a boom compared to a bust period. Generally, the results for the after-crisis period reveal no significant differences compared to the crisis times. Overall, over the sample period, our findings reveal that the foreign banks in Estonia, Latvia, Romania, Hungary and Bulgaria deleveraged more, while the foreign banks in Czechia, Poland and Slovakia deleveraged less.

Model (4) reveals differences related to foreign banks' lending behaviour during normal and turbulent times, triggered by a home-country effect. Specifically, the pro-cyclicality in the case of banks with German ownership is the lowest and the highest is in the case of banks with Austrian ownership. Also, the pro-cyclicality of domestic banks, estimated in model (2), is lower compared to banks with Austrian, Greek, French, Italian, Belgian and Swedish ownership. The findings also show that banks with Austrian, Greek, French and Italian ownership reduced their credit activity to a larger extent, both during and after the crisis period. For the crisis and after-crisis period, the multinomial log-odds for the banks with Belgian and Swedish ownership are not statistically significant. These findings match those of Iwanicz-Drozdowska and Witkowski (2016), who stressed that foreign banks should not be treated as a monolith. 
Table 3: Multinomial logit estimates

\begin{tabular}{|c|c|c|c|c|c|c|c|c|}
\hline & \multicolumn{2}{|c|}{1} & \multicolumn{2}{|c|}{2} & \multicolumn{2}{|c|}{3} & \multicolumn{2}{|c|}{4} \\
\hline & Boom & $\begin{array}{l}\text { After } \\
\text { crisis }\end{array}$ & Boom & $\begin{array}{l}\text { After } \\
\text { crisis }\end{array}$ & Boom & $\begin{array}{l}\text { After } \\
\text { crisis }\end{array}$ & Boom & $\begin{array}{l}\text { After } \\
\text { crisis }\end{array}$ \\
\hline Bank loan growth & $6.195^{* * * *}$ & $-1.948^{* * * *}$ & - & - & - & - & - & - \\
\hline $\begin{array}{l}\text { Cross-border bank } \\
\text { claims' growth }\end{array}$ & $8.722^{* * *}$ & $-1.856^{* * *}$ & - & - & - & - & - & - \\
\hline $\begin{array}{l}\text { Foreign banks' loan } \\
\text { growth }\end{array}$ & - & - & $7.618^{* * *}$ & $-2.106^{* * *}$ & - & - & - & - \\
\hline $\begin{array}{l}\text { Domestic banks' loan } \\
\text { growth }\end{array}$ & - & - & $5.035^{* * *}$ & $-1.824^{* * *}$ & - & - & - & - \\
\hline $\begin{array}{l}\text { Foreign banks' loan } \\
\text { growth in Bulgaria }\end{array}$ & - & - & - & - & $4.112^{* * *}$ & 0.211 & - & - \\
\hline $\begin{array}{l}\text { Foreign banks' loan } \\
\text { growth in Croatia }\end{array}$ & - & - & - & - & $2.656^{* * *}$ & -0.584 & - & - \\
\hline $\begin{array}{l}\text { Foreign banks' loan } \\
\text { growth in Czechia }\end{array}$ & - & - & - & - & $1.614^{* * *}$ & $-1.099^{*}$ & - & - \\
\hline $\begin{array}{l}\text { Foreign banks' loan } \\
\text { growth in Estonia }\end{array}$ & - & - & - & - & $8.190^{* *}$ & 0.866 & - & - \\
\hline $\begin{array}{l}\text { Foreign banks' loan } \\
\text { growth in Hungary }\end{array}$ & - & - & - & - & $4.124^{* * *}$ & -0.122 & - & - \\
\hline $\begin{array}{l}\text { Foreign banks' loan } \\
\text { growth in Latvia }\end{array}$ & - & - & - & - & $6.752^{* * * *}$ & 1.130 & - & - \\
\hline $\begin{array}{l}\text { Foreign banks' loan } \\
\text { growth in Lithuania }\end{array}$ & - & - & - & - & $3.004^{* *}$ & 0.962 & - & - \\
\hline $\begin{array}{l}\text { Foreign banks' loan } \\
\text { growth in Poland }\end{array}$ & - & - & - & - & $0.443^{*}$ & $-0.731^{*}$ & - & - \\
\hline $\begin{array}{l}\text { Foreign banks' loan } \\
\text { growth in Romania }\end{array}$ & - & - & - & - & $4.293^{* * *}$ & -0.353 & - & - \\
\hline $\begin{array}{l}\text { Foreign banks' loan } \\
\text { growth in Slovakia }\end{array}$ & - & - & - & - & -0.031 & -0.387 & - & - \\
\hline $\begin{array}{l}\text { Foreign banks' loan } \\
\text { growth in Slovenia }\end{array}$ & - & - & - & - & $2.542^{* * * *}$ & $-1.676^{* *}$ & - & - \\
\hline $\begin{array}{l}\text { Austrian-owned banks' } \\
\text { loan growth }\end{array}$ & - & - & - & - & - & - & $10.081^{* * *}$ & $-9.874^{* * *}$ \\
\hline $\begin{array}{l}\text { Belgian-owned banks' } \\
\text { loan growth }\end{array}$ & - & - & - & - & - & - & $-15.193^{* * * *}$ & -4.023 \\
\hline $\begin{array}{l}\text { French-owned banks' } \\
\text { loan growth }\end{array}$ & - & - & - & - & - & - & $7.566^{n+*}$ & $-4.414^{* * *}$ \\
\hline $\begin{array}{l}\text { German-owned banks' } \\
\text { loan growth }\end{array}$ & - & - & - & - & - & - & $2.063^{* * * *}$ & $1.792^{* * *}$ \\
\hline $\begin{array}{l}\text { Greek-owned banks' } \\
\text { loan growth }\end{array}$ & - & - & - & - & - & - & $11.151^{* * *}$ & $-5.273^{* * *}$ \\
\hline $\begin{array}{l}\text { Italian-owned banks' } \\
\text { loan growth }\end{array}$ & - & - & - & - & - & - & $9.395^{* * * *}$ & $-3.005^{* * *}$ \\
\hline $\begin{array}{l}\text { Swedish-owned banks' } \\
\text { loan growth }\end{array}$ & - & - & - & - & - & - & $12.954^{* * *}$ & 1.596 \\
\hline Log-likelihood & \multicolumn{2}{|c|}{$-1,096.192$} & \multicolumn{2}{|c|}{$-1,354.697$} & \multicolumn{2}{|c|}{-590.876} & \multicolumn{2}{|c|}{-602.696} \\
\hline LR $\times 2$ & \multicolumn{2}{|c|}{$1,206.280$} & \multicolumn{2}{|c|}{689.27} & \multicolumn{2}{|c|}{613.68} & \multicolumn{2}{|c|}{569.58} \\
\hline Pseudo R2 & \multicolumn{2}{|r|}{0.355} & \multicolumn{2}{|c|}{0.202} & \multicolumn{2}{|c|}{0.341} & \multicolumn{2}{|c|}{0.320} \\
\hline $\begin{array}{l}\text { Number } \\
\text { of observations }\end{array}$ & \multicolumn{2}{|r|}{1,686} & \multicolumn{2}{|c|}{1,686} & \multicolumn{2}{|r|}{893} & \multicolumn{2}{|r|}{893} \\
\hline
\end{tabular}

Note: ${ }^{* * *},{ }^{* * *},{ }^{*}$ correspond to the $1 \%, 5 \%$, and $10 \%$ levels of significance, respectively.

Source: Authors' calculations. 
Generally, the results disclose the volatility of foreign banks' credit growth rate, with a pronounced slope in turbulent times. Specifically, between 2008 and 2012, when the GFC and the European sovereign debt crisis (ESDC) reached their peaks, our results show that foreign banks deleveraged their exposure on CEE economies significantly, and the imbalances built up in good times were transformed into major vulnerabilities for the economic and financial stability. These were the bad times for the region. Furthermore, we see that some foreign banks continued to deleverage, even if the crisis effects disappeared. In this light, in some CEE countries, the risks exacerbated and a bank crisis followed. These were the ugly times, when the deleveraging process led to a credit crisis in Croatia, Hungary, Latvia, Lithuania, Romania and Slovenia (Duca et al., 2017). Our findings are in line with those of Haselmann et al. (2016), Cull et al. (2017), and Brzoza-Brzezina et al. (2018) who showed that, during crisis, foreign banks were a driver of financial fragility, particularly due to their potential to transmit external shock and amplify foreign spillovers. In the same light, Perić et al. (2018) emphasized the channel of international risk transfer enhanced by the nexus between home-country parent bank and host-country foreign owned bank, while Temesvary and Banai (2017) showed that the lower liquidity of the parent bank negatively impacted the lending of the subsidiary. Considering the pro-cyclicality differences in banks' lending behaviour, we emphasize the importance of having a balance in bank ownership market shares.

In response to the deleveraging process, the authorities and banks adopted several measures. Firstly, in a coordinated framework, banks and national authorities adopted the Vienna Initiative, with the purpose of limiting bank outflows from the region. Secondly, at the national level, the regulatory authorities adopted prudential measures in order to increase the resilience of the banking systems. For example, Bulgaria, Poland, Slovenia and Slovakia imposed profit distribution restrictions to limit capital transfers from subsidiaries to parent banks. Bulgaria, Slovenia and Slovakia tightened intergroup exposure limits to reduce interconnectedness and contagion risk. Hungary, Poland and Romania tightened loan-to-value and debt service-to-income ceilings for foreign currency loans. Budnik and Kleibl (2018) detail these prudential measures in their database, while Pochea and Niţoi (2021) assess their impact on loan growth in the CEE banking systems. Thirdly, some CEE governments have launched post-crisis banking reforms, aiming to reduce the dependence of their banking systems on foreign ownership. For instance, from 2013, Hungary adopted several policies, which have pushed down the share of their foreign-controlled banks from 62\% in 2008 to $43 \%$ in 2019 (European Central Bank, 2020). The same path was followed by Poland in 2015, motivated by the desire to see a greater portion of lending and financing decisions taken at home. As a result, the assets of foreign banks dropped in Poland from 73\% in 2008 to 46\% in 2019 (European Central 
Bank, 2020). Finally, banks adapted their asset and liability management strategies. Banks focused more on domestic and stable funds, they reduced the share of foreign currency loans, and they improved the asset quality and liquidity ratios. These patterns reshaped the banking systems' landscape in the CEE region and are going to play an important role in how banks will respond to different crisis events. The current Covid-19 crisis has not triggered liquidity dips similar to those from the GFC period, due to unprecedented central banks' non-standard measures to overcome the crisis. However, the banking systems will have to play a crucial role in spurring economic growth. In this context, the following years will also test the commitment of some foreign banks to CEE countries.

\section{Conclusions}

This article analysed foreign banks' behaviour in the CEE countries during the period 2000-2016, aiming to capture the link between bank loan growth, cross-border bank claims and the cycle period. Moreover, it explored the differences in foreign ownership behaviour during normal and turbulent times and identified whether host- and homecountry effects take place.

We summarize our findings as follows. Firstly, the paper finds a positive link between cross-border bank claims and loan growth in the CEE countries. There is evidence that bank loan growth manifests a pro-cyclical behaviour, which is more pronounced in the case of foreign banks. Moreover, the deleveraging process that banks started during the turbulent times continued in the aftermath of the crisis. Secondly, the results reveal clear differences in foreign banks' behaviour in relation with the economic cycle, highlighting the good and the bad times for the region. Thirdly, our results highlight that foreign banks' loan growth is influenced by both a host- and a home-country effect. However, the scale of this relation is distinct. The findings for the host-country effect show that foreign banks in Estonia, Latvia, Romania and Hungary were more prone to deleveraging, while foreign banks in Czechia, Poland and Slovakia deleveraged less. Also, the results for the homecountry effect show that the pro-cyclicality of lending behaviour is lower for banks with German ownership. Conversely, banks with Austrian, Greek and Italian ownership exhibit the highest pro-cyclicality in their lending patterns. However, to a minor extent, the same is true for the banks with French, Belgian and Swedish banks. Consequently, the banking systems where these foreign-owned banks had a significant market share were more vulnerable to financial outflows. These findings alongside the individual banks' business model could explain why some banking systems performed better in the region.

The dominant position of foreign banks in the CEE region has clearly boosted the development of a competitive and efficient banking system in the region. However, 
the GFC has also revealed the other side of the coin of this banking structure. It became clear that a banking system built largely on foreign ownership was too vulnerable to exogenous liquidity shocks associated with interbank and wholesale markets. In these circumstances, the authorities had to use prudential regulation in order to preserve economic and financial stability and strengthen cooperation with home-country authorities. Moreover, given the pro-cyclicality differences in banks' lending behaviour, policy makers should strive to establish a balance between domestic and foreign banks' market share, diversify the structure of foreign ownership and monitor the health of foreign parent banks.

Our findings could be extended by further research that should combine our results with data about individual banks' business models, consolidation practices and financial health indicators.

\section{References}

Allen, F., Beck, Th., Carletti, E., et al. (2011). Cross-Border Banking in Europe: Implications for Financial Stability and Macroeconomic Policies. London: Centre for Economic Policy Research. ISBN 978-1-907142-36-9

Allen, F., Jackowicz, K., Kowalewski, O., et al. (2017). Bank Lending, Crises, and Changing Ownership Structure in Central and Eastern European Countries. Journal of Corporate Finance, 42, 494-515, https://doi.org/10.1016/j.jcorpfin.2015.05.001

Arakelyan, M. (2018). Foreign Banks and Credit Dynamics in CESEE. International Monetary Fund. Washington, DC Working Paper No. 18/3, https://doi. org/10.5089/9781484336779.001

Avdjiev, S., McCauley, R., McGuire, P. (2012). Rapid Credit Growth and International Credit: Challenges for Asia. Bank for International Settlements. Basel. Working Papers No. 377.

Bakker, B., Gulde, A.-M. (2010). The Credit Boom in the EU New Member States: Bad Luck or Bad Policies? International Monetary Fund. Washington, DC Working Paper No. 10/130, https://doi.org/10.5089/9781455201136.001

Becker, T., Dăianu, D., Darvas, Z., et al. (2010). Whither Growth in Central and Eastern Europe? Policy Lessons for an Integrated Europe. Brussels: Bruegel Blueprint Series, Volume 11. ISBN 978-9-078910-17-6.

Berger, A. N. (2007). Obstacles to a Global Banking System: “Old Europe" versus "New Europe". Journal of Banking and Finance, 31(7), 1955-1973, https://doi.org/10.1016/j. jbankfin.2007.01.005

Berglöf, E., Korniyenko, Y., Plekhanov, A., et al. (2009). Understanding the Crisis in Emerging Europe. London: European Bank for Reconstruction and Development. Working Paper No. 109, https://doi.org/10.2139/ssrn.1536645

BIS (2017). BIS Statistical Bulletin, June 2017. Basel: Bank for International Settlements. 
BIS (2020). Statistics, Locational Banking Statistics [database]. Basel: Bank for International Settlements.

Blundell, R., Bond, S. (1998). Initial Conditions and Moment Restrictions in Dynamic Panel Data Models. Journal of Econometrics, 87(1), 115-143, https://doi.org/10.1016/ S0304-4076(98)00009-8

Bonin, J. P., Hasan, I., Wachtel, P. (2005). Bank Performance, Efficiency and Ownership in Transition Countries. Journal of Banking \& Finance, 29(1), 31-53, https://doi. org/10.1016/j.jbankfin.2004.06.015

Bonin, J. P., Louie, D. (2017). Did Foreign Banks Stay Committed to Emerging Europe during Recent Financial Crises? Journal of Comparative Economics, 45(4), 793-808, https://doi.org/10.1016/j.jce.2016.08.003

Borio, C., McCauley, R., McGuire, P. (2011). Global Credit and Domestic Credit Booms. Bank for International Settlements. BIS Quarterly Review. Available at: https://www.bis.org/ publ/qtrpdf/r_qt1109f.pdf

Brunnermeier, M., De Gregorio, J., Eichengreen, B., et al. (2012). Banks and Cross-Border Capital Flows: Policy Challenges and Regulatory Responses. Brookings Institution, Committee for International Economic Policy and Reform. Available at: https://www.brookings.edu/ wp-content/uploads/2016/06/09-ciepr-banking-capital-flows.pdf

Bruno, V., Shin, H. S. (2012). Capital Flows, Cross-border Banking and Global Liquidity. AFA 2013. San Diego Meetings Paper, https://doi.org/10.2139/ssrn.2020556

Brzoza-Brzezina, M., Kolasa, M., Makarski, K. (2018). Crisis, Contagion and International Policy Spillovers under Foreign Ownership of Banks. Journal of Financial Stability, 36, 293-304, https://doi.org/10.1016/j.jfs.2018.03.006

Budnik, K. B., Kleibl, J. (2018). Macroprudential Regulation in the European Union in 1995-2014: Introducing a New Data Set on Policy Actions of a Macroprudential Nature. European Central Bank. Working Paper Series No. 2123.

Cetorelli, N., Goldberg, L. S. (2011). Global Banks and International Shock Transmission: Evidence from the Crisis. IMF Economic Review, 59(1), 41-76, https://doi.org/10.1057/imfer.2010.9

Chen, G., Wu, Y. (2014). Bank Ownership and Credit Growth in Emerging Markets During and After the 2008-09 Financial Crisis - A Cross-Regional Comparison. International Monetary Fund. Working Paper No. 14/171, https://doi.org/10.5089/9781484390993.001

Claessens, S., Demirgüç-Kunt, A., Huizinga, H. (2001). How Does Foreign Entry Affect Domestic Banking Markets? Journal of Banking and Finance, 25(5), 891-911, http://doi.org/10.1016/S0378-4266(00)00102-3

Claessens, S., van Horen, N. (2015). The Impact of the Global Financial Crisis on Banking Globalization. IMF Economic Review, 63(4), 868-918, https://doi.org/10.1057/ imfer.2015.38

Clarke, G. R., Cull, R., Martinez Peria, M. S. (2006). Foreign Bank Participation and Access to Credit across Firms in Developing Countries. Journal of Comparative Economics, 34(4), 774-795, https://doi.org/10.1016/j.jce.2006.08.001 
Cull, R., Pería, M. S. (2013). Bank Ownership and Lending Patterns during the 2008-2009 Financial Crisis: Evidence from Latin America and Eastern Europe. Journal of Banking \& Finance, 37(12), 4861-4878, https://doi.org/10.1016/j.jbankfin.2013.08.017

Cull, R., Pería, M. S., Verrier, J. (2017). Bank Ownership - Trends and Implications. International Monetary Fund. Washington, DC Working Paper No. 17/60.

De Haas, R., Korniyenko, Y., Pivovarsky, A., et al. (2015). Taming the Herd? Foreign Banks, the Vienna Initiative and Crisis Transmission. Journal of Financial Intermediation, 24(3), 325-355, https://doi.org/10.1016/j.jfi.2014.05.003

De Haas, R., Van Lelyveld, I. (2006). Foreign Banks and Credit Stability in Central and Eastern Europe. A Panel Data Analysis. Journal of banking \& Finance, 30(7), 1927-1952, https://doi.org/10.1016/j.jbankfin.2005.07.007

De Haas, R., Van Lelyveld, I. (2014). Multinational Banks and the Global Financial Crisis: Weathering the Perfect Storm? Journal of Money, Credit and Banking, 46(s1), 333-364, https://doi.org/10.1111/jmcb.12094

Drakos, A. A., Kouretas, G. P., Tsoumas, C. (2016). Ownership, Interest Rates and Bank Risktaking in Central and Eastern European Countries. International Review of Financial Analysis, 45, 308-319, https://doi.org/10.1016/j.irfa.2014.08.004

Duca, L. M., Koban, A., Basten, M., et al. (2017). A New Database for Financial Crises in European Countries: ECB/ESRB EU Crises Database. European Central Bank. Frankfurt am Main Occasional Paper No. 194.

European Central Bank (2020). Statistical Data Warehouse, Supervisory and Prudential Statistics [database]. Frankfurt am Main: European Central Bank.

Fišerová, T., Teplý, P., Tripe, D. (2015). The Performance of Foreign-Owned Banks in Host Country Economies. Prague Economic Papers, 24(5), 538-561, https://doi.org/10.18267/j. pep.527

Hasan, I., Marton, K. (2003). Development and Efficiency of the Banking Sector in a Transitional Economy: Hungarian Experience. Journal of Banking \& Finance, 27(12), 2249-2271, https://doi.org/10.1016/S0378-4266(02)00328-X

Haselmann, R. (2006). Strategies of Foreign Banks in Transition Economies. Emerging Markets Review, 7(4), 283-299, https://doi.org/10.1016/j.ememar.2006.09.002

Haselmann, R., Wachtel, P., Sobott, J. (2016). Credit Institutions, Ownership and Bank Lending in Transition Economies, in Beck, T., Casu, B., eds. The Palgrave Handbook of European Banking. London: Palgrave Macmillan, pp. 623-643, https://doi.org/10.1057/9781-137-52144-6_24

Havrylchyk, O., Jurzyk, E. (2011). Inherited or Earned? Performance of Foreign Banks in Central and Eastern Europe. Journal of Banking and Finance, 35(5), 1291-1302, https://doi.org/10.1016/j.jbankfin.2010.10.007

Impavido, G., Rudolph, H., Ruggerone, L. (2013). Bank Funding in Central, Eastern and South Eastern Europe Post Lehman - a "New Normal"? International Monetary Fund. Washington, DC Working Paper No. 13/148, https://doi.org/10.5089/9781484391082.001 
Iwanicz-Drozdowska, M., Witkowski, B. (2016). Credit Growth in Central, Eastern, and SouthEastern Europe: The Case of Foreign Bank Subsidiaries. International Review of Financial Analysis, 43, 146-158, https://doi.org/10.1016/j.irfa.2015.11.010

Klingen, C. (2013). Perspectives on Growth Prospects for Central, Eastern and Southeastern Europe, in Kolev, A., Zwart, S., eds., Banking in Central and Eastern Europe and Turkey Challenges and Opportunities. Luxembourg: European Investment Bank, pp. 13-25.

Lapteacru, I. (2016). Bank Risk in Central and Eastern European Countries: Does Ownership Matter? Monetary Economics: Financial System \& Institutions eJournal, http://doi.org/10.2139/ssrn.2801977

Montoro, C., Rojas-Suarez, L. (2012). Credit at Times of Stress: Latin American Lessons from the Global Financial Crisis. Bank for International Settlements. Basel Working Paper No. 370.

Niţoi, M., Clichici, D., Moagăr-Poladian, S. (2019). The Effects of Prudential Policies on Bank Leverage and Insolvency Risk in Central and Eastern Europe. Economic Modelling, 81, 148-160, https://doi.org/10.1016/j.econmod.2018.12.016

Perić, B. Š., Smiljanić, A. R., Aljinović Z. (2018). Credit Risk of Subsidiaries of Foreign Banks in CEE Countries: Impacts of the Parent Bank and Home Country Economic Environment. The North American Journal of Economics and Finance, 46, 49-69, https://doi. org/10.1016/j.najef.2018.03.009

Pochea, M. M., Nițoi, M. (2021). The Impact of Prudential Toolkits on Loan Growth in Central and Eastern European Banking Systems. Economic Systems, 45(1), 100767, https://doi.org/10.1016/j.ecosys.2020.100767

Roodman, D. (2009). How To Do Xtabond2: An Introduction to Difference and System GMM in Stata. The Stata Journal, 9(1), 86-136, https://doi.org/10.1177/1536867X0900900106

Temesvary, J., Banai, A. (2017). The Drivers of Foreign Bank Lending in Central and Eastern Europe: The Roles of Parent, Subsidiary and Host Market Traits. Journal of International Money and Finance, 79, 157-173, https://doi.org/10.1016/j.jimonfin.2017.08.005 